\section{Suverent om angst og smerte}

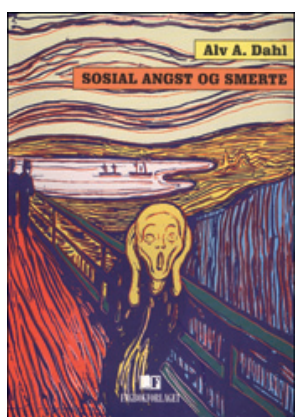

Alv A. Dahl

\section{Sosial angst og smerte}

321 s, tab, ill. Bergen: Fagbokforlaget, 2012.

Pris NOK 448

ISBN 978-82-450-1075-6

Målgruppen er først og fremst personer tilknyttet helse- og omsorgssektoren, men boken er, som forfatteren angir, aktuell for alle.

Alv A. Dahl tar for seg sosial angst og smerte med et vidt perspektiv. De to første kapitlene omhandler angstbegrepet ut fra nevrobiologiske og psykologiske synsvinkler. Her beskriver han både tidligere og moderne teorier for å forstå angstbegrepet. I de andre kapitlene tar han for seg sosial angst og smerte i forbindelse med ulike situasjoner - intimitet, avhengighet, prestasjoner og sjalusi. På slutten presenterer forfatteren ulike aspekter ved mobbing i arbeidslivet og ostrakisme, i tillegg til høyaktuelle synspunkter på mediedrevkonseptet. På en elegant måte besvarer forfatteren spørsmålet om hvor mye problemer og vansker sosial angst og smerte kan skape for dem som blir rammet.

Boken er logisk oppbygd, ryddig og lettlest. Omslaget med Andy Warhols versjon av Munchs Skrik fungerer utmerket. Personlig satte jeg stor pris på sitater, dikt og aforismer fra forfattere og filosofer fordi det underbygger det faglige stoffet. Ikke bare gjør det boken mer forståelig, men jeg tror også det bidrar til en dypere forståelse av stoffet. Etter hvert kapittel er det en passende oppsummering og sammenfatning, i tillegg til en aktuell referanseliste.

Det finnes en rekke lettleste selvhjelpsbøker på markedet for folkesykdommene angst og depresjon. Mange av dem er preget av en patologisering av menneskelivet. Denne boken er annerledes. Den hevder ikke å være en selvhjelpsbok, men kan fungere som det. Det er mye god terapi i psykoedukasjon. Forfatteren beskriver ulike forståelsesmodeller for psykisk uhelse uten å ta standpunkt til hvilke av teoriene som er best. Jeg tror det er en bok mange vil bli klokere av å lese.

Savner jeg noe? Ja! Ulike typer terapi og behandling har kun fått ett kapittel på slutten. Nå skal det sies at det eksplisitt står at det ikke er hensikten. Jeg skulle ønske meg en bok nummer to om ulike kunnskapsbaserte intervensjoner for sosial angst - i samme språklig treffsikre stil og med samme oppbygging.

Boken inneholder mye nyttig kunnskap som leger i alle spesialiteter vil ha glede av. Jeg anbefaler den på det varmeste.

\section{Jan Ivar Røssberg}

Regionalt kompetansesenter for tidlig intervensjon ved psykoser, TIPS Sør-Øst

Oslo universitetssykehus

\section{Å reise seg etter en smell}

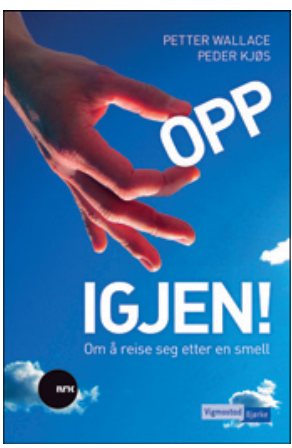

Petter Wallace, Peder Kjøs

\section{Opp igjen!}

$\mathrm{Om}$ å reise seg etter en smell. $212 \mathrm{~s}$. Bergen

Vigmostad \& Bjørke, 2012. Pris NOK 269

ISBN 978-82-419-0772-2

Forfatterne henvender seg til alle som har opplevd en krise eller gått på en smell. Det er en optimistisk bok som understreker hvor viktig det er å ta aktivt grep om egen situasjon. Det er ikke nok å sette seg til og vente på bedringen. Boken er ment som supplement til annen behandling.

Forfatterne er journalisten som gikk på en smell, og hans psykolog. Fastlege Jørgen Skavlan har skrevet forordet. Utover i boken glir begrepet «å gå på en smell» over i andre ord, som uro, angst, krise og depresjon. Derfor beskriver forfatterne aktive strategier for å mestre slike følelser og tilstander også.

Det er 15 kapitler, inkludert utdrag av pasientjournalen, et eget kapittel om behandling og et kapittel om de pårørendes situasjon og rolle. Noen gjentakelser er det blitt - på grunn av oppdelingen i så mange kapitler.

Boken er gjennomsyret av at man ikke må undervurdere alvoret i tilstanden til den som har gått på en smell, møtt veggen, møtt lettveggen eller hva nå man kaller fenomenet.

Teksten er seriøs og velskrevet og inneholder mye livsvisdom, selverkjennelse, gode råd og trøst. Den utleverer ikke forfatterens personlige drama, men evner å generalisere rundt angst, uro, livskriser og depresjon.

Jeg tenker at den appellerer spesielt til menn som har gått på en smell, og jeg tror mange menn vil kunne identifisere seg med pasienten. Begge forfatterne er menn, og de bruker noen maskuline metaforer som at angsten er en «feilmelding», «alarmsystemer» og «supertriggere». Men det er på ingen måte slik at boken er uinteressant for kvinner.

Jeg anbefaler alle som selv har vært i nærheten av å gå på en smell, og deres ektefeller/partnere, å lese denne boken. Spesielt mener jeg at alle fastleger burde lese den. Min erfaring er at fastleger, $i$ allianse med særlig de mannlige pasientene, kan ha en tendens til å bagatellisere alvoret og kompleksiteten i smellen.

\section{Synnøve Bratlie}

Dr. Bratlies spesialistpraksis

Oslo 